\title{
A post-mortem qualitative radiographic study of the foot with special reference to the digital lesions in culling lame cows
}

\author{
Mohsen Nouri ${ }^{1, *}$, Alireza Vajhi ${ }^{1}$, Seyyed Hossein Marjanmehr ${ }^{2}$, Iradj Nowrouzian ${ }^{1}$, \\ Davoud Faskhoudi ${ }^{1}$
}

${ }^{1}$ Department of Clinical Sciences, Faculty of Veterinary Medicine, the University of Tehran, Tehran, Iran

${ }^{2}$ Department of Pathology, Faculty of Veterinary Medicine, the University of Tehran, Tehran, Iran

\section{Email address:}

mnouri2@yahoo.com(M. Nouri)

\section{To cite this article:}

Mohsen Nouri, Alireza Vajhi, Seyyed Hossein Marjanmehr, Iradj Nowrouzian, Davoud Faskhoudi. A Post-Mortem Qualitative Radiographic Study of the Foot with Special Reference to the Digital Lesions in Culling Lame Cows. Animal and Veterinary Sciences. Vol. 1, No. 4, 2013, pp. 27-31. doi: 10.11648/j.avs.20130104.11

\begin{abstract}
This cross-sectional and descriptive study was carried out on 43 samples of culled lame cows with digit disorders which were collected from slaughterhouse. After recording information for each cow, at least four radiographs were taken from amputated limb. New bone formation, osteolysis, soft tissue swelling and gas density were indices considered for assessing the severity of the disease. The prevalence rate of claw lesion among all cases was 69.7 per cent. Most lesions were mainly due to the effect of non-infectious lesions such as toe ulcer $(3 ; 6.9 \%)$, white line disease $(5 ; 11.6 \%)$, heel ulcer $(6 ; 13.9 \%)$, abaxial groove lesions $(7 ; 16.2 \%)$ and sole ulcers $(9 ; 20.9 \%)$, respectively. There were $20.5 \%$ and $79.5 \%$ cows with locomotion scores of 4 and 5 , respectively. The most prominent radiographic abnormalities were noted in the P3 region of culling lame cows: widened vascular channels (23.2 \%), extensor process entheseophyte (62.7 \%), flexor tuberosity entheseophyte $(65.1 \%)$, osteolysis at the tip of the pedal bone $(9.3 \%)$, osteolysis of the plantar tuberisity (58.1\%) and abaxial wall (6.9 \%), chip fracture (2.3\%), pathologic fracture (18.6\%), symmetric swelling $(23.2 \%)$, asymmetric swelling $(69.7 \%)$ and gas density into the claw $(9.3 \%)$. Septic arthritis and increase in joint width (18.6\%), bony ankylosis and subluxation (13.9 \%) were noted in the Joints. In conclusion, radiography revealed the extent of osseous changes in cattle affected with laminitis, provided valuable additional information and confirmed the diagnosis and prognosis where a normal clinical examination seems inadequate.
\end{abstract}

Keyword: Claw, Cow, Deep Septic, Digit, Lameness, Radiology

\section{Introduction}

Lameness is considered to be a major welfare and economic problem of dairy. Economically, lameness due to lose in milk yield, weight and fertility and increases the risk of culling $[1,2,3]$. Next to mastitis and reproductive failure, lameness is an important cause of involuntary culling in dairy herds. Its annual incidence ranges between 4 and 55 cases per 100 cows per year [4]. Effect of lameness on culling is not clear-cut, because several authors have reported little or no increase in culling due to lameness $[1,5,6]$. The decision to cull a cow is complicated, with many factors influencing that decision, notably, age (parity), milk production, fertility, and health [7]. On the other hand, because of the low level of farmer's knowledge, training and awareness, the risk of digital disease not being discovered until the clinical condition becomes very obvious. At that stage, the process responsible for the lameness is usually quite advanced and results in infection of bone and related tissue increases the risk of premature slaughter [3, 8, 9]. However, early and accurate diagnosis is vital in cases of bovine lameness. The chances of restoring the productivity of the animal, its milk yield or weight gain, depend largely on rapid medical or surgical treatment, the course of which relates directly to accurate diagnosis and appropriate treatment. In these instances, a radiographic assessment is often necessary and in most cases, useful to reach to a diagnosis [3, 10, 11, 12, 13, 14, 15].

The purpose of this study was to investigate and quantitate radiological findings in digital region of culled lame cows, with special reference to the lesions and their distribution. 


\section{Materials and Methods}

This cross-sectional and descriptive study was carried out in the winter of the year 2009 at Meysam abattoir in the vicinity of Tehran (RobatKarim). Forty three culled lame cows of 1135 culled Holstein cows having digit disorders which were randomly selected for qualitative radiographical purpose. The owners were interviewed using a questionnaire to record pre-mortem information. All cases aged three to eight years; both front legs and hind legs were amputated at the carpal and the tarsal region, respectively, immediately after slaughter, examined and tabulated the type and distribution of foot lesions.

The digital region of amputated limb was cleaned thoroughly with water and a brushed before radiography to be able to exactly diagnose the kind of injury in the radiographic projections. The amputated limbs were admitted to the Radiology Section of Tehran University Veterinary Hospital for more routine radiographical studies. Four radiographs were taken from each case, in lateralmedial or medial-lateral, dorsopalmar/dorsoplantar, dorsolateral-palmaromeledial / dorsolateral-plantaromedial and dorsomedial-palmarolateral / dorsomedialplantaromedial. Radiographs were recorded by the mammography cassettes in sizes of $18 \times 24$ and $24 \times 30$, and the required exposure factors of $85-95 \mathrm{KV}, 25 \mathrm{~mA}$ in $0 / 04-$ 0/02 seconds (Toshiba, DC-12M, Japan). New bone formation, osteolysis, soft tissue swelling, and gas density were indices considered for assessing the severity of the disease. At the visits, the locomotion scores of all of the lame cows $(n=43)$ were recorded. The locomotion score was determined by two observers working together. Each animal was observed standing and walking (on a concrete surface whenever possible) using the Sprecher scoring system [16]. Finally, the findings were discussed descriptively.

\section{Results}

Radiographic images taken from the involved digits of the forty three culled lame cows depicted a quite wide range of radiographic signs such as soft tissue swelling, new bone formation, osteolysis and gas density which were observed mostly in the hind limbs. All signs were relatively the same as forelimbs and the hind limbs. These signs were distributed in different sizes; they were more significant considering the increased infection and the involvement of other neighboring structures, such as coffin's joint, distal sesamoid bone and even the adjoining digit bones. Radiological examinations showed that chronic lesions of claw are accompanied by alterations in the structure of phalanxes. In most of cases chronic osteophytes of extensor tendon was seen at insertion on the extensor process as well as calcification of the deep flexor tendon on PIII bone. Four out of the total of 43 cases showed osteolysis at the tip of the pedal bone $(9.3 \%)$. Twenty-one out of the total of 43 cases showed periosteal new bone formation on the volar process, extensor process and plantar tuberisity, and also these cases had osteolysis on the caudal part of the plantar tuberisity of P3 bone $(48.8 \%)$. Table 1 illustrates the radiographic changes in the distal phalanx. Complete fractures of metacarpal and metatarsal bone, however, were rare in this study but accounted for 2 out of 43 cases of lameness in culling lame cow.

Table 1: Bone and soft tissue alterations of the distal phalanx of forty three culled lame cows at the radiologic examination

\begin{tabular}{|c|c|c|c|c|}
\hline Type of lesions of P3 & & $\begin{array}{l}\text { Fore limb } \\
\text { No. of cases (\%) }\end{array}$ & $\begin{array}{l}\text { Hind limb } \\
\text { No. of cases (\%) }\end{array}$ & $\begin{array}{l}\text { Total } \\
\text { No. of cases }(\%)\end{array}$ \\
\hline Widened vascular channels & & $1(2.3)$ & $9(20.9)$ & $10(23.2)$ \\
\hline \multirow{3}{*}{ Fracture } & Sequestration (Pathologic) & $2(4.6)$ & $6(13.9)$ & $8(18.6)$ \\
\hline & Chip & - & $1(2.3)$ & \\
\hline & Toe & $1(2.3)$ & $3(6.9)$ & $4(9.3)$ \\
\hline \multirow[t]{3}{*}{ Pedal Osteolysis } & Plantar tuberisity & $3(6.9)$ & $22(51.1)$ & $25(58.1)$ \\
\hline & Abaxial wall & - & $3(6.9)$ & $3(6.9)$ \\
\hline & Symmetric & $2(4.6)$ & $8(18.6)$ & $10(23.2)$ \\
\hline \multirow[t]{3}{*}{ Type of digital Swelling } & Asymmetric & $6(13.9)$ & $24(55.8)$ & $30(69.7)$ \\
\hline & No Swelling & $1(2.3)$ & $2(4.6)$ & $3(6.9)$ \\
\hline & Volar process & $4(9.3)$ & $23(53.4)$ & $27(62.7)$ \\
\hline \multirow{2}{*}{$\begin{array}{l}\text { Periosteal New Bone } \\
\text { Formation }\end{array}$} & Extensor process & $5(11.6)$ & $22(51.1)$ & $27(62.7)$ \\
\hline & Plantar tuberisity & $4(9.3)$ & $24(55.8)$ & $28(65.1)$ \\
\hline Gas density into the claw & & - & $4(9.3)$ & $4(9.3)$ \\
\hline
\end{tabular}

Thirty one out of the total of 43 cases showed periosteal new bone formation on the P2 and P3 bones (72.0\%). Table 2 illustrates the radiographic changes in the proximal and middle phalanges.

Septic arthritis accounted for 8 out of the total of 43 cases found $(18.6 \%)$. About $75.0 \%$ of arthritis was observed in distal inter-phalangeal joint.

Fifteen out of the total of 43 cases showed periosteal new bone formation on the lateral and medial surface, and also these cases had osteolysis on the dorsal surface of sesamoid 
bone (34.8\%). Table 3 illustrates the radiographic changes in the distal sesamoid bone.

Thirty cases were affected by lesions in different regions of claw capsule $(69.7 \%)$. Most lesions were mainly due to the effect of non-infectious lesions such as toe ulcer $3(6.9 \%)$, white line disease $5(11.6 \%)$, heel ulcer 6 (13.9\%), abaxial groove lesions $7(16.2 \%)$ and sole ulcers 9 (20.9\%), respectively. The prevalence rate of claw lesion in the hind limb was higher than fore limb. Lacerations, fracture, penetrating injuries, interdigital lesion such as IDN, ID were other digital lesion in this study.

All cases showed signs of disability in weight bearing. Problems with weight bearing, arching of the backbone, lowering of the head and holding abducted of the affected limb were considered as the significant clinical features, in evaluation of locomotion scoring. Locomotion scoring assessment of 43 culled lame cows showed score ranged from grade $4(20.5 \%)$ to $5(79.5 \%)$ on a scale of 1 to 5 .

Table 2: Bone and soft tissue alterations of the proximal and middle phalanx of forty three culled lame cows at the radiologic examination.

\begin{tabular}{|c|c|c|c|c|c|c|}
\hline & \multicolumn{3}{|c|}{ Type of lesions of P1 } & \multicolumn{3}{|c|}{ Type of lesions of P2 } \\
\hline & Fore limb & Hind limb & Total & Fore limb & Hind limb & Total \\
\hline & $\begin{array}{l}\text { No. of cases } \\
(\%)\end{array}$ & $\begin{array}{l}\text { No. of cases } \\
(\%)\end{array}$ & $\begin{array}{l}\text { No. of cases } \\
(\%)\end{array}$ & $\begin{array}{l}\text { No. of cases } \\
(\%)\end{array}$ & No. of cases (\%) & No. of cases $(\%)$ \\
\hline Osteolysis & $1(2.3)$ & $3(6.9)$ & $4(9.3)$ & $2(4.6)$ & $12(27.9)$ & $14(32.5)$ \\
\hline Periosteal New Bone Formation & $6(13.9)$ & $28(65.1)$ & $34(79.0)$ & $7(16.2)$ & $29(67.4)$ & $36(83.7)$ \\
\hline \multirow{2}{*}{ Fracture } & - & - & - & - & $6(13.9)$ & $6(13.9)$ \\
\hline & - & $1(2.3)$ & - & - & $1(2.3)$ & $1(2.3)$ \\
\hline $\begin{array}{l}\text { Gas density into the } P 1 \text { and } P 2 \\
\text { region }\end{array}$ & $2(4.6)$ & $2(4.6)$ & $4(9.3)$ & $1(2.3)$ & $8(18.6)$ & $9(20.9)$ \\
\hline
\end{tabular}

Table 3: Radiographic changes in the sesamoid bone of forty three culled lame cows.

\begin{tabular}{|c|c|c|c|c|}
\hline \multicolumn{2}{|l|}{ Type of lesions of sesamoid bone } & $\begin{array}{l}\text { Fore limb } \\
\text { No. of cases (\%) }\end{array}$ & $\begin{array}{l}\text { Hind limb } \\
\text { No. of cases (\%) }\end{array}$ & $\begin{array}{l}\text { Total } \\
\text { No. of cases }(\%)\end{array}$ \\
\hline \multirow[t]{2}{*}{ Pathologic Fracture } & & - & $5(11.6)$ & $5(11.6)$ \\
\hline & Dorsal Surface & $2(4.6)$ & $14(32.5)$ & $16(37.2)$ \\
\hline \multirow[t]{3}{*}{ Osteolysis } & Lateral Surface & $1(2.3)$ & - & $1(2.3)$ \\
\hline & Medial Surface & $1(2.3)$ & - & $1(2.3)$ \\
\hline & Dorsal Surface & - & - & - \\
\hline \multirow[t]{2}{*}{ Periosteal New Bone Formation } & Lateral Surface & $2(4.6)$ & $18(41.8)$ & $20(46.5)$ \\
\hline & Medial Surface & $2(4.6)$ & $20(46.5)$ & $22(51.1)$ \\
\hline Gas density & & - & $3(6.9)$ & $3(6.9)$ \\
\hline Bony Ankylosis & & - & $5(11.6)$ & $5(11.6)$ \\
\hline
\end{tabular}

\section{Discussion}

In this study, radiography has been limited to the digital region of culling lame cows. On radiographic examination, a considerable amount of new bone formation, osteolysis and gas density within the affected digit were observed. The best way of detailed differential diagnosis of these lesions is radiography. However, radiographic signs of foot infection should be interpreted in conjunction with other clinical information.

In radiographs, soft tissue swelling was a common sign for lame cows with digital lesions. Soft tissue swelling proximal to the hoof wall is a consistent finding in cattle with foot infections $[2,3,11]$. In our experience, all culled lame cattle with asymmetrically swollen digit had deep sepsis of the digit. In cases with septic osteitis of the digital bone, the swelling was appeared focally in bulb heel of the involving digit which can be proper factors for the prognosis of the digital bone changes.

Periostitis commonly occurs in the phalanges, leading to exostosis. In the present study, this condition was seen mostly in the hind limbs. Calcifications of the deep flexor tendon as well as osteophytes of the common digital extensor tendon insertion on the third phalanx were the most commonly involved structures. It has been claimed that exostosis of the deep flexor tendon at its point of insertion, is seen at the point directly dorsal to many cases of ulceration of the sole [14]. But in this study calcifications of the deep 
flexor tendon on the third phalanx were not related to sole ulcer, specifically. This finding agrees with those of other workers [17]. Greenough (1981) suggested that increase in size of the plantar process is a consequence of ageing, assumed to arise from traction by ligaments [18]. In the lame cows, excessive tension due to abnormal weight bearing and abnormal stance can also influence calcifications of the deep flexor tendon and the common digital extensor tendon on the third phalanx [3, 19]. Gantke et al. (1998) suggested that changes in shape of the extensor process, shape of the dorsal surface of P3 were judged as physiologic variations [20]. Zantiga (1973) observed that not all open lesions of the sole are associated with pedal bone change [15]; osteolysis or proliferative changes are secondary to an inflammatory reaction or develop progressively due to either persistence of external lesions or as result of aseptic or septic complications [12]. The findings are in contrast to the findings of Rusterholz (1920) who observed exostosis of the plantar process and at insertion of the flexor tendon in solar ulceration [14].

Maclean (1970) suggested that the presence of this lesion could be used as an aid to diagnose laminitis in barley-fed beef cattle [21]. Therefore, the prevalence of osteopathy in the P III bone of the culling lame cows is further evidence that laminitis occurred in this group of animal. Greenough (1990) suggested that osteopathy of the apex of the distal phalanx is related to intensive feeding which is consistent with the concept of ruminal acidosis induced laminitis [22].

In this study, post mortem examination revealed that typical changes of chronic laminitis were among the most common pathological features, suggesting that laminitis may have affected virtually all the herd at some previous time.

Pedal osteolysis was second in importance in dairy cows, and accounted for 32 out of 43 cases found (74.4\%). The most common lesion, osteolysis of plantar tuberisity was found in 22 animals $(51.1 \%$ of the total). In interpretation of pedal osteolysis, various radiographic changes were found on the toe, plantar tuberisity and abaxial wall of P3 bone; these signs are due to the persistence of the external lesion. When the corium is exposed, infection can invade the deeper structures of the claw and travel proximally to involve the claw structures, resulting in necrosis of the P III bone. Nuss et al. (1996) suggested that the osteolysis and pedal osteitis in the region of the laminae at the dorsal edge of $\mathrm{P} 3$ are considered signs of laminitis [23].

In cases with toe ulcer, two of them showed toe fracture and the entheseophyte of the extensor process was $66.6 \%$. Osteolysis of the tip of $\mathrm{P} 3$ is common following septic traumatic pododermatitis at the pedal bone tip. Inexperience claw trimmers tend to over trim the horn sole and to grind off the sole wall edge excessively and an infection of the corium at the toe region leads to a direct involvement of the pedal bone rapidly due to the very thin layer of curium and digital cushion in this area [24]. It has been claimed that clinical signs of apical pedal bone necrosis varied widely depending on the severity of the lesions [24]. However, the location of exposed lesion on the digital region is more important than severity of lesion. Since contact with ground surface can be an excessive painful condition and explain the severe stilted movements often seen in these animals.

In cases with white line disease, most of them showed solar margin bone absorption, flexor tuberisity entheseophyte, extensor process entheseophyte. One of them showed bone sequestration of P3 bone. Hashemi et al. (2005) studied the radiographic appearance of 20 cow digits, with signs of white line disease [25]. The most prominent radiographic abnormalities of the claw artery included perivascular sclerosis $(100.0 \%)$ and vascular dilations $(90.0 \%)$. Other important findings included extensor process entheseophyte $(80.0 \%)$, solar margin irregularities $(65.0 \%)$, flexor tuberisity entheseophyte $(40.0 \%)$, solar surface bone proliferation $(40.0 \%)$, dorsal wall bone proliferation and solar margin bone absorption $(45.0 \%)$.

In cases with heel ulcer, most of them showed extensor process entheseophyte and osteolysis of the plantar tuberisity on the P3 bone.

In cases with abaxial groove lesions, most of them showed osteolysis of the abaxial wall margin. Flexor tuberosity entheseophyte and extensor process entheseophyte were seen. Two of them showed septic arthritis.

The high percentage $(18.6 \%)$ of bone sequestration is not surprising in culling lame cows. The formation of sequestrum is due to a loss of endosteal blood supply from thrombosis of branches of the nutrient artery [26]. The dead bone is separated and is surrounded by purulent material. Ultimately, fibrous tissue and new bone will be formed in the medullary canal with subperiosteal new bone covering the sequestrum. The sequestra slow healing and reparative process, allowing bacteria to persist. They may also be a source of reinfection [26].

On radiographic examination, markedly widened vascular channel on the dorsal surface were observed in about $23.2 \%$ of cases. In chronic cases, the widened vascular channels were considered sign of laminitis, $[3,10$, 21] whereas the other observations also were made in affected claw. Boosman (1990) studied the arteriographic appearance of bovine hind digits, with microscopic signs of chronic laminitis [27]. The most Prominent arteriographic abnormalities of the digital artery include dilatation and a tortuous, irregular course. Maclean (1970) observed similar changes in laminitic fore- claws of barley beef animals. The vascular channels in the pedal bone were dilated [21].

Gas density, however, was rare in this study but accounted for 4 out of 43 cases in both $\mathrm{P} 1$ and $\mathrm{P} 2$ regions (9.3\%) and 9 for P2 region (20.9\%). The multiple foci of gas of variable size and shape indicate presence of an abscess in the swollen soft tissue [10]. The low percentage of gas density is not surprising, because the occurrence of abscess is common in acute case and not chronic case such as most culling lame cows in this study.

In conclusion, radiography revealed the extent of osseous 
changes in cattle affected with laminitis, provided valuable additional information and confirmed the diagnosis and prognosis where a normal clinical examination seems inadequate.

\section{Acknowledgments}

The slaughterhouse staff is acknowledged for their assistance in the preparation of abattoir specimens. The authors are particularly indebted to Dr. Afshin Motaghi-far (the Chief meat inspector in Meysam Slaughterhouse, RobatKarim road) for supporting this work. This study was funded by Faculty of Veterinary Medicine, the University of Teheran (Teheran, Iran).

\section{References}

[1] Esslemont RG, Kossaibati MA. Culling in 50 dairy herds in England. Vet Rec. 1997; 140 (2): 36-39.

[2] O'Brien RT, Biller DS. Clinical applications of radiography and ancillary imaging. Vet Clinic North Am, Food Anim. $1996 ; 12,263-275$

[3] Nouri M, Vajhi A, Nowrouzian I, Marjanmehr SH, Faskhoudi D. "Rusterholz" ulcer in culling cows: clinical and radiographic interpretation. Iran J Vet Surg. 2008; 3(1): 29-36.

[4] Whitaker DA, Kelly JM, Smith EJ. Incidence of lameness in dairy cows. Vet Rec. 1983; 113(3): 60-62.

[5] Booth CJ, Warnick LD, Grohn YT, Maizon DO, Guard CL, Janssen D. Effect of lameness on culling of dairy cows. J Dairy Sci. 2004; 87(12): 4115-4122.

[6] Cramer G, Lissemore K, Kelton D, Guard Ch, Leslie K. The association between hoof lesion and culling risk in Ontario dairy cows. Proceedings of the American Association of Bovine Practitioner, 2006; 39: 242-243.

[7] Jubb TF, Malmo J. Lesions causing lameness requiring veterinary treatment in pasture-fed dairy cows in east Gippsland. Aust Vet J. 1991; 68(1): 21-24.

[8] Bargai U. Applied techniques for diagnosis of lameness in cattle. Proceedings of the $\mathrm{Vl}^{\text {th }}$ International Symposium on Diseases of the Ruminant Digit, 16 Jul, Liverpool, UK. 1990; 42-44.

[9] Greenough PR. Observations on some of the diseases of the bovine foot. Part II. Vet Rec. 1962; 74: 53-63.

[10] Bargai U. Radiological diagnosis of the foot, In: Bargai U, Pharr J, Morgan JP. (Eds): Bovine Radiology. Ames, IA, Iowa state University Press. 1989; 29-64.

[11] Farrow JW. Digital infection in cattle, their radiologic spectrum. Vet Clinic North Ame, Food Anim. 1985; 1: 53-65.

[12] Moldovan M, Bolte S., Igna C. Radiological research on the phalangeal changes in pododermatitis circumscripta in cattle. Proceedings of the $6^{\text {th }}$ International Symposium on Diseases of the Ruminant Digit, 16-20 July, Liverpool, UK. 1990; 269-275.

[13] Nouri M., Nowrouzian I, Vajhi A, Marjanmehr SH, Faskhoudi D. Ankylosis of the digit bones in six culling lame cows. Iran J Vet Surg. 2007; 2(3): 66-77.

[14] Rusterholz A. The specific traumatic sole ulcer of claws in cattle. Schweizer Archiv Fur Tierheilkunde 1920; 62: 421466.

[15] Zantiga JW. A comparative radiological and clinical study of the typical lesion of the sole (ulceration of the sole) in cattle. Neth J Vet Sci. 1973; 5: 88-97.

[16] Sprecher DJ, Hostetler DE, Kaneene JB. A lameness scoring system that uses posture and gait to predict dairy cattle reproductive performance. Theriogen. 1997; 47(6): 11791187.

[17] Lisher Ch J, Koller U, Geyer H, Ossent P, Auer JA. Relation between radiological findings at claws and the healing process of sole ulcer in dairy cow. Tierarztl Prax. 2001; 29(3), 122-127.

[18] Greenough PR, Mac Callum FJ, Weaver AD. Lameness in cattle. 2nd edn. Bristol John Wright and Sons. 1981; 70-81.

[19] Moser E. and M. Westhues, Leitfaden der hufund klauenkrankheiten stuttgar: Enk, 1950; 35-89.

[20] Gantke S, Nuss K, Kostlin R. Radiologic findings in bovine laminitis. Tierarztl Prax Ausg Grosstiere Nutztiere. 1998; 26(5): 239-46.

[21] Maclean CW. A post-mortem x-ray study of laminitis in barley beef animals. Vet Rec. 1970; 86(16): 457-462.

[22] Greenough PR, Vermunt JJ, McKinnon JJ, Fathy FA, Berg PA, Cohen RDH. Laminitis-like changes in the claws of feedlot cattle. Can Vet J. 1990; 31(3): 202-208.

[23] Nuss K, Gantke S, Kostlin R, Fuhrmann U. Radiology of laminitis in cattle. Proceedings of the $19^{\text {th }}$ world buiatrics, 812 July, Edinburgh, Scotland, GB, 1996; 126.

[24] Kofler J. Clinical study of toe ulcer and necrosis of the apex of the distal phalanx in 53 cattle. Vet J. 1999; 157(2):139147.

[25] Hashemi M., A. Veshkini, Nowrouzian I. Radiographic feature of white line disease in dairy cattle. Proceeding of the $4^{\text {th }}$ Convention of Iranian Veterinary Clinicians, 31 May2 June, Urmia, Iran, 2005; 175-6 (in Farsi).

[26] Orsini JA. Strategies for treatment of bone and joint infections in large animals. J Ame Vet Med Assoc 1984; 185(10): 1190-3.

[27] Boosman, R. Bovine laminitis; histologic and arteriography aspects, and its relation to endotoxaemia. Faculty of Veterinary Medicine, University of Utrecht. Utrecht, Netherlands. 1990. 